\title{
The Review of Theoretical Bankruptcy Banking After the Global Financial Crisis
}

\author{
Shinta Hidayatul Ummah, Suhartono, and Abdul Mongid \\ Department of Management, STIE Perbanas Surabaya, Surabaya \\ e-mail:shintahidayatulummah@gmail.com
}

\begin{abstract}
Every company is vulnerable to bankruptcy, including banking industry. Bankruptcy of a bank will have an effect on other industries, because it as intermediation institution. If the intermediation process is stalled, the payment system will stall and disturb economic activities. Therefore research about indicator to predict the bankruptcy is important. Risk management must be implemented to detect and manage risk arising from bank operations. Banks can manage bankruptcy risk from the efficiency side. This study focus on the effect financial ratio (Return on Assets and Equity to Total Assets), size bank, and macroeconomic to bankruptcy predictions. Most of the bank's revenue from credit, it is on the asset side in the balanced sheet. If the bank has small assets then potentially have financial distress. The paper aims to conceptually and based on theoretical review studies. There are signaling and efficiency theory as basic theories related with these concept. By classifying the result of previous research, found some propositions: Return on Asset, Equity to Total Asset, Size Bank, Inflation and Gross Domestic Product are able to predict bank bankruptcy. The research believes that the proposition of this study result can be tested empirically mainly in banking industry.
\end{abstract}

Keywords-Bankruptcy, Financial Ratio, Size, Inflation, Gross Domestic Product.

\section{INTRODUCTION}

$\mathrm{F}$ ROM 2007 to 2008 it was a heavy year for the world economy. The world is faced with a global financial crisis impacting all countries. Alan Greenspan, former governor of The US Central Bank (The Fed) mentions that this crisis as a ' once-in-a-century ' financial crisis that will and continues to bring an impact on the global economy. The crisis originated in the United States, as the world's number one economy, the crisis also impacted more sectors in the world including the banking sector.

The bank is defined as a financial institution that has a business license operate as a bank, i.e. accepting the placement of funds - Community entrusted to the bank, channeling credit to the and the business world in general, gives expectations for various the bank's form of debt and publishes a cheque. Banking has the main function to raise funds from the community and then channel back to the community for activities production, distribution and consumption. In conducting its business as a financial institution that sells trust and services, every bank strives as much as possible attracting new customers, enlarging funds and also enlarging giving credit and services - his services banking is an important sector for the economy in all countries. Banking sector stability becomes a major factor in maintaining stability Financial and economic systems. The economic crisis can cause bankruptcy, such as bad credit. High competition makes banks more active and productive distribute credit and other banking products to master the sector macro and micro. Banks are more focused to pursue profits and less risks that may arise from the competition.

Bankruptcy of one bank not only causes problems in the individual banks but can cause effects in other industries. This is because banking has a role as an intermediation institution. If the banking intermediation process is interrupted resulting in a payment system and a lump of economic activity. The consequences of bankruptcy in the banking sector can negatively impact the entire economy.

Financial distress conditions that are not handled appropriately by the bank will be able to make the bank bankruptcy and forced liquidated. This will harm the external parties, especially investors. This condition not only provides the impact of liquidation or bankruptcy in Bank, but can also affect the economic condition.

The risk of bank failure occurs when the bank fails to carry out its operational activities or there is a loss in the bank's business for several years. The Bank is unable to pay its debts to customers, especially short-term debts such as Giro, savings and deposits. Risks are often associated with uncertainty. Uncertainty is a situation that is unpredictable. Basically predicting can give you an idea or forecast of possibilities that occur in the future so as to avoid things that can harm.

Risk management is an important thing to implement in the banking world. Risk management as a procedure to detect and manage risks arising from the operational activities of the Bank. If the bank is able to manage the risks, the bank's expected return will be increased. Conversely, if the risk is not well managed will increase the probability of bankruptcy. The declared Bank fails to be saved or not saved depending on regulatory authority.

Banks can manage bankruptcy risk from the efficiency side. One indicator that can measure banking efficiency is Cost to Income Ratio (CIR). Cost to Income Ratio is a ratio that shows how much cost a bank has to earn in revenue. Every activity that banks do in obtaining income requires a sacrifice to do including expenses incurred.

Every activity that banks do in obtaining income requires a sacrifice to do including expenses incurred. According to Wasis (1993:120) cost is one factor that contributes to high low profitability. In the banking industry, efficiency is not only used to view operational performance and management, 
The $1^{\text {st }}$ International Conference on Business and Engineering Management (IConBEM)

February $1^{\text {st }} 2020$, Institut Teknologi Sepuluh Nopember, Surabaya, Indonesia

but also plays a crucial role in seeing the probability of a company experiencing bankruptcy. Banks that have bankruptcy generally begin with low levels of efficiency [1].

Banks who are unable to compete to maintain their performance will be eliminated from their industrial environment and are experiencing bankruptcy. Therefore, in anticipation of the various risks that may occur, action is required to measure the conditions and health of the banking. The emergence of various bankruptcy predictive models is an anticipation and early warning system against the possibility of the financial crisis.

Profit-making capabilities are an important aspect of the company, including banking. Profitability is used to measure the effectiveness of banks in gaining profits. Besides being used as a measure of financial health, the profitability ratio is crucial to be observed given that adequate gains are needed to maintain the current source of bank capital. Return On Asset is used to measure the bank's management capability in obtaining profits (profit before tax) resulting from the average total bank asset in question.

Rina's research (2014) Shows that Return On Asset contributes the greatest contribution so that Return On Asset is the most defining variable for categorizing banks into groups that are expected to experience problematic conditions or not. Meanwhile, according to Dian, et al (2017) Profitability in the Return On Asset variable cannot be used as a predictor of the bank-based crisis prediction Banking Sector Fragility Index di Indonesia. This indicates that almost all bank management strives to increase profits, so that each bank seeks to comply with applicable legislation to be categorized into a healthy bank.

Different when most bank assets are not funded by their own capital, indicates that the bank has a weak level of control over the under the control of other parties. The magnitude of capital contribution assets can be viewed through equity ratios with total assets or equity to total assets. Equity ratio with total assets showing percentage of investments in the total assets that have been spent with funds originating from the capital own. The ratio of own capital to total assets reflects relative importance from its own loan and capital funds and the level of security for creditors.Equity to Total Asset is a financial indicator used to measure the attachment or motivation of the owner on the business continuity of the relevant bank.

According Chen-Min, dkk (2019) Equity to Total Asset significantly affects the probability of failure of banks in East Asia, North America and Western Europe. Ching-Chung Research results, et al (2015) Also shows that Equity to Total Asset can reduce the probability of failure of banks in East Asia. While research Alexandre, et al (2016) Indicates that Equity to Total Asset is not able to predict failure in the banking sector.

Size is a scale whereby banks can be classified by a large amount according to various means, among others, based on the total assets or asset owned. The bank size can describe how much total assets a company has and how big the company is. The use of total assets as the size of the company because assets are a picture of the company's wealth at certain time and period. Generally large companies that have a total of large assets are able to produce a large profit. Large companies have their own appeal to consumers of big companies tend to risk bankruptcy because the number of assets tends to be larger.

Putri and Merkusiwati (2014) and Ni Putu (2015) stated that the bank with large size is more stable is the ability of the bank in the serialization of financing activities so as to minimize the occurrence of financing risk. In other words, the size relates negatively to the risk of bankruptcy. Larger-asset banks have a smaller risk than small-assets banks. Major banks tend to avoid risks and are more obedient to policy set. However research Laura, et al (2016) Indicates that the Size has a positive relationship with the failure of the bank, whereby banks with larger assets have greater risk and can harm their chances of enduring.

Bankruptcy banks can be influenced by environmental circumstances. One external factor that can predict a bank bankruptcy is inflation. Inflation is a general increase in prices and lasts continuously within a certain span of time. Inflation has made economic intricately and improved poverty rate. Two-digit inflation triggered by the slowing of price oil world has proved to be a lot of messing events the world economy over the last few decades so many cause problems. Even the impact of inflation perceived by the community the poor is much greater than the inflation rate itself. Inflation has been depresised the value of wealth and real income of society so decrease in purchasing power. In such circumstances the company is wrapped by a cost Increased production costs and marketing.

Ching, et al (2015) That inflation is capable of measuring the probability of failure of banks in East Asia while according to Dian, et al (2017) and Norfaizah, et al (2018) Insignificant inflation in determining the banking financial crisis. Dian, et al (2017) stated that Bank Indonesia's monetary policy to manage price pressures in order to maintain the rate of inflation can be maintained at a low and stable level, making the influence of inflation less adverse to financial conditions.

Gross Domestic Product Growth is a macro economic indicator that affects bank profitability. Economic growth can increase the cash flow of banks by increase the demand for financing by companies and households. For strong economic growth period financing demand tends to increase. Because the financing of Cederung produce better profits from investing in marketable securities, expected cash flow will be more high. Another reason for the high cash flow is the fewer risk levels that occurred during the period of strong economic growth.

Chen-Min Research, et al (2019) and Ching-Chung, et al (2015) states that Gross Domestic Product growth significantly affects the probability of failure of the bank. According Norfaizah, et al (2018) and Dian, et al (2017) Gross Domestic Product growth is not significant in determining the financial crisis of banking. The increase in Gross Domestic Product growth in Indonesia is more used for consumption than saving or investing so Gross Domestic Product growth does not affect the community investing and doing credit demand. So the impact given by the decline and 
The $1^{\text {st }}$ International Conference on Business and Engineering Management (IConBEM)

February $1^{\text {st }} 2020$, Institut Teknologi Sepuluh Nopember, Surabaya, Indonesia

increase in Gross Domestic Product growth is not too perceived by banks in Indonesia [2].

Based on the research that has been done previously there is inconsistency of the results obtained. From some of the research presented above there are several studies stating that Return On Average Asset, Equity to Total Asset, Size, Inflation and Gross Domestic Product growth are significantly able to predict bank bankruptcy, but There are some studies stating that such variables are incapable of predicting bank bankruptcy. Therefore, researchers are interested to reexamine Return On Average Asset, Equity to Total Asset, Size, Inflation and Gross Domestic Product growth as variables capable of predicting bank bankruptcy.

\section{A. Signaling Theory}

The signal theory suggests about how a company should give signals to users of financial statements. Signals are interpreted as cues made by the company (the manager) to outside parties (investors). These signals can be tangible in various forms, either directly observable or that should be done in-depth study to know [3].

Scott (2012) Describes a signal that is defined as a peak management action that is irrational if done by a lower management. Signal giving is a management business that has more information than investor (asymmetric information) but strives to present it to investors to increase investment decision. According Melati \& Sulistyawati (2016) Signal is an action taken by the management of the company where the management knows more complete and accurate information about the company's internal and future prospects than the investors.

Therefore, the manager is obliged to give signals on the company's condition to the stakeholders. The signals provided can be made through the disclosure of accounting information such as publication of financial statements. The manager publishes financial statements to provide information to the market. Generally the market will respond to such information as a good news or bad news signal. The signal is intended to imply something in the hopes of the market or external parties will make changes to the company's valuation. That is, the selected signal must contain the power of information to be able to change the assessment of the external company.

\section{B. Efficiency Theory}

The concept of efficiency according to Berger and Mester (1997) Divided into three parts, namely cost efficiency, profit efficiency and the efficiency of the alternative advantages. This concept is ideal because it is based on economical optimisation in response to market prices and competitions, not merely looking at technical efficiency. Cost efficiencies are defined as how close a company is at the most optimal cost utilization to produce the same level of output as the same condition. The profit efficiency is how close the company is in generating the most ideal output at the price level of certain inputs and outputs. The efficiency of the alternative advantage has a thought that some assumptions contained in cost efficiency and profit efficiency, not used in models so that the concept can be more realistic in capturing real conditions.

In the banking industry, efficiency is not only used to look at operational performance and management, but also play an important role in seeing the probability of a company experiencing bankruptcy. Banks that have bankruptcy generally begin with low levels of efficiency [1].

Efficiency and effectiveness can not be known only through the magnitude income gained by the bank, as costs and revenues have a fairly close relationship, where revenues arise due to costs. A bank can be said to be efficient when the bank can use the cost of to earn an optimal income. The relationship between this cost and income can be known by using cost income ratio. Cost income ratio is the ratio of comparison to the cost of total income.

One indicator that can measure banking efficiency is Cost to Income Ratio (CIR). Cost to Income Ratio is a ratio that shows how much cost a bank has to earn in revenue. Every activity that banks do in obtaining income requires a sacrifice to do including expenses incurred. According Wasis (1993:120) Cost is one factor that contributes to high low profitability. This ratio can be used to see the quality of the management of banks. The lower the cost to income ratio, the better the quality of the management. This ratio also demonstrates the efficiency of bank operations. According Veithzal, et al (2013 : 482) Cost to Income Ratio (CIR) is a comparison of operational costs with operating income to measure the level of efficiency and ability of the bank to operate.

Cost income ratio represents the bank's ability to manage financial. This Cost income ratio should be seen in a few years, Because it can be used better if viewed in a period. If the cost Bank's income ratio down from year to year, the bank can be said Increased efficiency. If otherwise, the Bank is experiencing decreased efficiency. Decreasing the efficiency of these banks if not immediately resolved can caused the bank to be stuck in financial distress, because the bank large enough to earn revenue, and allow banks to have difficulties fulfilling their obligations.

\section{Bankruptcy Bank}

Bank bankruptcy is a condition or situation in which the company undergoes shortage and inadequacy of funds to continue its business. Bank bankruptcy is an event of failure or inability of a company to fulfill obligations to the debtor because the company is experiencing inadequacy of funds in running its business so that the goal to get Profit is not fulfilled [4]. According Lia Rachmawati dan Wiwik Fitria (2018), explained that the failed Bank is caused by 2 things, including: first, the bank needs financial support or management support from the Government in carrying out its operational activities. Secondly, based on the health of the bank.

Bankruptcy banks are often referred to by company liquidation, company closure and insolvency [5]. Bankruptcy is a very severe financial difficulty so that the company feels unable to run the company's operations properly, while Financial Distress is a financial difficulty or liquidity that may be the first source of of a bankruptcy. It is important to 
The $1^{\text {st }}$ International Conference on Business and Engineering Management (IConBEM)

February $1^{\text {st }} 2020$, Institut Teknologi Sepuluh Nopember, Surabaya, Indonesia

do a bank bankruptcy analysis to detect the health of the bank. Bank bankruptcy analysis can be interpreted as a failure of the company in carrying out the company's operations, so that the company's main objectives cannot be achieved [6]. The benefit of conducting a bank bankruptcy analysis is to provide early warning regarding predicting the occurrence of bank bankruptcy.

\section{Return on Asset}

Profitability is used to measure the effectiveness of banks in gaining profits. Besides being used as a measure of financial health, the profitability ratio is crucial to be observed given that adequate gains are needed to maintain the current source of bank capital. Profit-making capabilities are an important aspect of the company, including banking. Return On Asset (ROA) is used to measure the management capability of the bank in obtaining profits (profit before tax) resulting from the average total bank asset in question. Profit before tax is net profit from the operational activities before tax. While the average total asset is the average volume of business or assets. Return On Average Assets is used to evaluate whether the management has received an adequate (reasobable return) reward from the underlying asset. ROA ratio can be used as a tool to analyse and measure the level of business efficiency and profitability achieved by banks. The larger the Return On Asset, the greater the profit level the bank has achieved, so it is likely that a bank in problematic conditions is getting smaller.

\section{E. Equity to Total Asset}

As time goes by, banks will try to develop its business in a variety of ways. One is to add assets to support the business and increase productivity. In increase the number of assets, banks can use their own capital as well as investor funds. When most bank assets are funded by their own capital, indicates that the bank has a strong control over the and not under the control of other parties. Different when most bank assets are not funded by their own capital, indicates that the bank has a weak level of control over the under the control of other parties. The magnitude of capital contribution assets can be viewed through equity ratios with total assets or equity capital to total assets. Equity ratio with total assets showing percentage of investments in the total assets that have been spent with funds originating from the capital own. The ratio of own capital to total assets reflects relative importance from its own loan and capital funds and the level of security for creditors.

Equity to Total Asset (ETA) is a financial indicator used to measure the attachment or motivation of the owner on the business continuity of the relevant bank. Quantitatively, this indicator is the proportion of equity with the total asset or assets. The higher the proportion of capital itself, the higher the attachment or motivation of the owner of the bank's business continuity. This ratio also shows the availability of capital to maintain the liquidity (Protective function) and its operational continuity so as to protect the owners of capital from bankruptcy or bankruptcy. The role of the owner is able to encourage management to improve the performance efficiency that will affect the profit obtained by the company, other than that the existence of capital can protect customers from losses arising and maintain the trust of the community because the capital available keep their funds.

\section{F. Size}

According Asngari (2013) Size is a scale whereby banks can be classified by a large amount according to various means, among others, based on the total assets or asset owned. The bank size can describe how much total assets a company has and how big the company is. The use of total assets as the size of the company because assets are a picture of the company's wealth at certain time and period. Generally large companies that have a total of large assets are able to produce a large profit. Large companies have their own appeal to consumers of big companies tend to risk bankruptcy because the number of assets tends to be larger.

\section{G. Inflation}

Inflation is an increase in the general price level in an economy that lasts continuously over time. Samuelson and Nordhaus (2001) Describes inflation as a disease and number one enemy in the economy. Inflation resulted in the effect of distribution of income and prosperity due to differences in the assets and debts held by the public. Inflation resulted in a distortion effect because the economy experienced efficiency issues and total output scoring issues. Economic efficiency issues occur due to distortions in price and use of money, while the total output assessment issue occurs because inflation encourages economic actors to adjust the valuation of prices and the presence of such adjustments cost is not minimal.

Inflation has made economic intricately and improved poverty rate. Two-digit inflation triggered by the slowing of price oil world has proved to be a lot of messing events the world economy over the last few decades so many cause problems. Even the impact of inflation perceived by the community the poor is much greater than the inflation rate itself. Inflation has been depresised the value of wealth and real income of society so decrease in purchasing power. In such circumstances the company is wrapped by a cost Increased production costs and marketing.

\section{H. Gross Domestic Product}

Gross Domestic Product (GDP) is used to measure all goods and services produced by a country in a certain period. Components in Gross domestic product i.e. income, expenditure/investment, government expenditure and exportimport difference. Stiglitz and Walsh (2006) explained that Gross domestic product provides the best assessment for measuring production levels. Gross Domestic product represents the overall level of economic activity in a country, i.e. the number of goods and services produced for a market. It shows that GDP is an indicator of growth an important measure of economic performance. Which is directly the performance of the economic actors providing goods and services including the banking industry.

Economic growth can increase the cash flow of banks by increase the demand for financing by companies and households. For strong economic growth period financing demand tends to increase. Because the financing of Cederung 
The $1^{\text {st }}$ International Conference on Business and Engineering Management (IConBEM)

February $1^{\text {st }} 2020$, Institut Teknologi Sepuluh Nopember, Surabaya, Indonesia

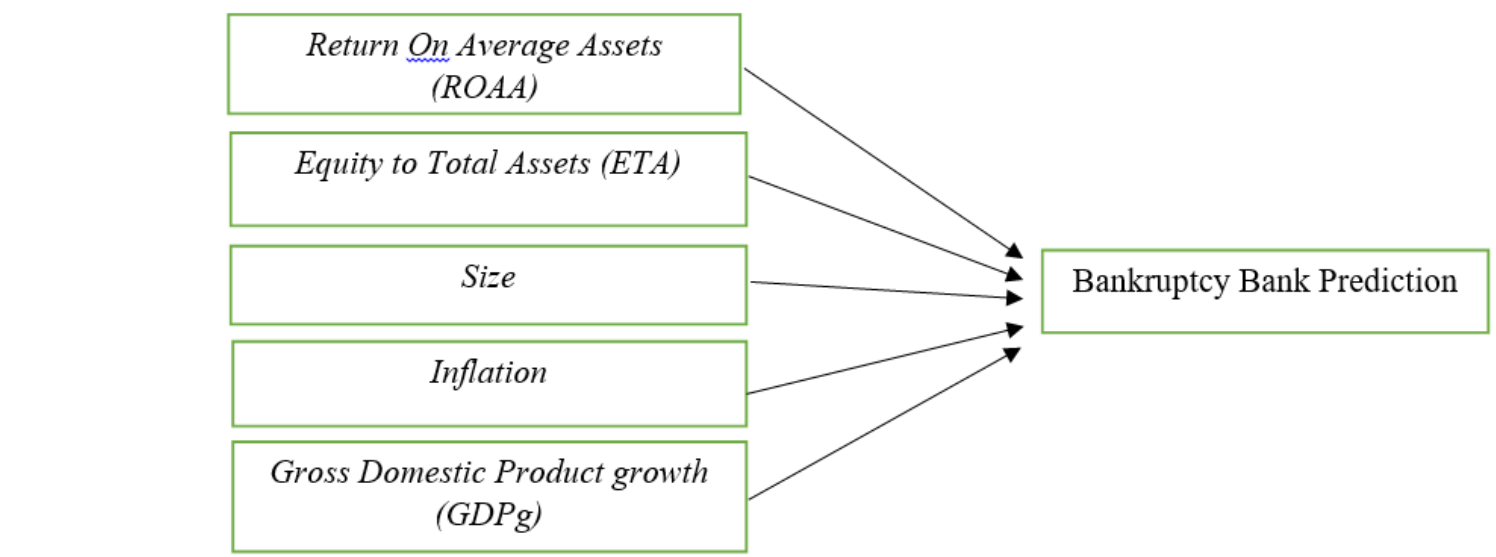

Figure 1. Framework

produce better profits from investing in marketable securities, expected cash flow will be more high. Another reason for the high cash flow is the fewer risk levels that occurred during the period of strong economic growth.

In relation to problematic loans, in recession conditions (visible Decrease in GDP) where sales and revenue decline occurred company, it will affect the company's ability Return the loan. This will lead to increased outstanding Non-current credits. Meanwhile, when the GDP Increased in theory to increase economic transactions, the business world, so that non-performing financing drops. Annual Gross Domestic product growth can be used to reflect the business cycle [7]. It shows that Gross domestic product is an indicator of economic growth which is an important measure in explaining the economic performance that is directly a performance of the economic actors who provide goods and services including banking industry.

This research aims to analyse the factors that predict the bank's bankruptcy so as to minimize the likelihood of failure on the bank.

\section{METHOD}

The paper is conceptual and qualitative in nature. It originated from some mainstream publications. Both sources are essential in developing the conceptual theory of bank bankruptcy. This research uses dependent and independent variables, namely:

\section{A. Dependen variable}

Bank bankruptcy predictions (Y)

\section{B. Independen variables :}

1. Return on Average Asset (X1)

2. Equity to Total Assets (X2)

3. Size (X3)

4. Inflation (X4)

5. Gross Domestic Product growth (X5)

\section{RESULTS AND DISCUSSION}

Based on the descriptions that have been described earlier, the results of this study can be seen in Figure 1.

\section{A. Ability to Return on Average Assets in Predicting Bank Bankruptcy}

Return On Average Assets is one of the profitability ratios that can measure the company's ability to generate profit from the assets used. Return On Average Assets is used to measure the management capability of the bank in obtaining profit resulting from the average total bank asset in question. The greater the Return On Average Assets, the greater the profit level the bank has achieved, so the probability that a bank in problematic conditions is getting smaller.

Rina's research (2014) Indicates that Return On Average Assets contributes to the greatest contribution so that Return On Average Assets is the most defining variable for categorizing banks into groups that are expected to experience problematic conditions or not. Meanwhile, according to Dian, et al (2017) Profitability in the Return On Average Assets variable can not be used as a predictor of banking crisis based on the banking Sector Fragility Index in Indonesia.

\section{B. Ability to Equity to Total Assets in Predicting Bank Bankruptcy}

The ratio of equity to total assets shows the percentage of investments in the total assets that have been budget with the funds originating from the capital itself. The ratio of its own capital to total assets reflects the relative importance of its own loan and capital funds and the level of security for the creditors. The increase in equity ratio is expected to lower the likelihood of bankruptcy because the greater equity indicates that the smaller the portion of the debt in the bank which then lowers the likelihood of bankruptcy.

Equity ratio with total assets shows the percentage of investments in total assets that have been budget with funds derived from their own capital. The ratio of own capital to total assets reflects the relative importance of funds. Increased equity ratio is expected to lower the likelihood financial distress because the greater equity indicates that the smaller the portion of the debt in the bank which then lowers the chances of financial distress.

By Chen-Min, et al (2019) Equity to Total Asset significantly affects the probability of failure of banks in East Asia, North America and Western Europe. Ching-Chung Research results, et al (2015) Also shows that Equity to Total 
The $1^{\text {st }}$ International Conference on Business and Engineering Management (IConBEM)

February $1^{\text {st }} 2020$, Institut Teknologi Sepuluh Nopember, Surabaya, Indonesia

Asset can reduce the probability of failure of banks in East Asia. While research Alexandre, et al (2016) Indicates that Equity to Total Asset is not able to predict failure in the banking sector.

\section{Ability to Size in Predicting Bank Bankruptcy}

Large-size banks are known to be more stable in facing economic condition. That's because large banks can manage risk well because they get used to asset management activities. Good asset management can be beneficial to the bank, thus avoid liquidity problems, leverage and capital so that it can support the operational activities undertaken and improve the health of the bank. Putri and Merkusiwati (2014) and Ni Putu (2015) stated that the bank with large size is more stable is the ability of the bank in the serialization of financing activities so as to minimize the occurrence of financing risk. However research Laura, et al (2016) Indicates that Size has a positive relationship with the failure of the bank.

\section{Ability to Inflation in Predicting Bank Bankruptcy}

Changes in inflation and interest rates are monetary habits that can affect the performance of financial institutions. Indirect inflation will have an impact on the customer's ability and interest in banking. This led to a bankruptcy of the bank.

By Aviliani, et al (2015) Increase in inflation can lead to an increase in the operational costs of banks, so assuming operating income is fixed then BOPO value will increase. Inflation can also increase credit risk and potential for loan payments, so the NPL increases. Ching, et al (2015) that inflation is capable of measuring the probability of failure of banks in East Asia while according to Dian, et al (2017) and Norfaizah, et al (2018) Insignificant inflation in determining the banking financial crisis.

\section{E. Ability to Gross Domestic Product Growth in Predicting Bank Bankruptcy}

Gross Domestic product growth decreases the likelihood of bankruptcy. Low growth indicates a decrease in economic activity from both the real and financial sectors. When the real sector growth declines, production will be hampered and will ultimately affect the banking sector as an institution facilitating credit distribution. If credit in banking is experiencing problems it will affect the likelihood of bankruptcy. Most of the banking profits gained from credit.

Chen-Min Research, et al (2019) and Ching-Chung, et al (2015) stated that Gross domestic product significantly affects the probability of failure of the bank. According to Norfaizah, et al (2018), Dian, et al (2017) and Laura, et al (2016) Gross Domestic product is not significant in determining the financial crisis banking.

\section{REFERENCES}

[1] A. N. Berger, W. C. Hunter, and S. G. Timme, "The efficiency of financial institutions: A review and preview of research past, present and future," J. Bank. Financ., vol. 17, no. 2-3, pp. 221249, 1993, doi: 10.1016/0378-4266(93)90030-H.

[2] D. Hamida, N. Ahmar, and S. Djaddang, "Determinan prediksi krisis perbankan berbasis banking sector fragility index," JIAFE (Jurnal Ilm. Akunt. Fak. Ekon., vol. 3, no. 2, pp. 1-16, 2018, doi: 10.34204/jiafe.v3i2.687.

[3] T. . Gumanti, "Teori sinyal dalam manajemen keuangan," Manaj. Usahaw. Indones., vol. 38, pp. 4-13, 2009.

[4] L. Afiqoh and N. Laila, "Pengaruh kinerja keuangan terhadap risiko kebangkrutan bank umum syariah di Indonesia (Mwtode Altman Z-score modifikasi periode 2011-2017)," J. Ekon. dan Bisnis Islam, vol. 4, no. 2, p. 166, 2018, doi 10.20473/jebis.v4i2.10757.

[5] I. Y. Fauzia, "Mendeteksi kebangkrutan secara dini perspektif Ekonomi Islma," EKUITAS (Jurnal Ekon. dan Keuangan), vol. 19, no. $1, \quad$ pp. 90-109, 2018, doi: 10.24034/J25485024.Y2015.V19.I1.92.

[6] E. Minda and N. Susanti, "Analisis kebangkrutan PT Bank Centra Asia (Persero) Tbk dan PT Bank Negara Indonesia (Persero) Tbk Periode 2011-2013," J. Akunt. Bisnis dan Ekon., vol. 1, no. 2, pp. 207-218, 2015.

[7] B. Wibowo and W. Ham, "Dampak risiko default bank terhadap risiko sistemik perbankan dan risiko sistematik bursa saham di lima negara ASEAN," J. Keuang. dan Perbank., vol. 20, no. 1, pp. 63-74, 2016, doi: 10.26905/jkdp.v20i1.149. 